\title{
Reporting under fear and threats: The deadly cost of being a journalist in Pakistan and India
}

\author{
Sadia Jamil ${ }^{1}$ \\ Khalifa University of Science \& Technology, UAE \\ Prabhjot Sohal \\ Panjab University, India
}

To cite this article: Jamil, S., \& Sohal, P. (2021). Reporting under fear and threats: The deadly cost of being a journalist in Pakistan and India. World of Media. Journal of Russian Media and Journalism Studies 2. DOI: 10.30547/worldofmedia.2.2021.1

\begin{abstract}
The journalists' right to perform their watchdog role and to do their routine jobs without fear of being killed, kidnapped, harassed, and attacked is a topic of utmost importance for freedom of the media and freedom of expression. However, in the past decade, journalists' killings across the globe indicate that journalism is no more a safe profession. Noticeably, the Asia-Pacific region is the third worst violator of media freedom in the world. While the level of media freedom and journalists' safety is not better in the Middle East and the North African regions, the Asia-Pacific region stands out because it is home to the two of the top ten worst countries for journalists' killings over the past 25 years, namely: Pakistan and India. Therefore, drawing on the system theory, this study aims to investigate the journalists' lived experiences of diverse safety risks in Pakistan and India. To accomplish this aim, this study uses the qualitative methods of document reviews and in-depth interviews. Besides, this study uses thematic analysis to analyse the gathered data. The analyses of journalists' lived experiences of safety risks reveal a stark systemic failure to protect them and safeguard their right to freedom of expression in these two countries.
\end{abstract}

\section{Keywords}

Journalism practice, safety risks, journalists' lived experiences, the Pakistani journalists, the Indian journalists, system theory.

\section{${ }^{1}$ Corresponding author:}

Sadia Jamil, Khalifa University of Science \& Technology, Near Home WTC AUH, Airport Road, Masdar City, Abu Dhabi, UAE.

Email: sadia.jamil@ymail.com 


\section{Introduction}

Journalism is now recognized as one of the deadliest professions around the world (Carlsson \& Poyhatri, 2017; Jamil \& Appiah-Adjei, 2020a). Violence continues to pestilence journalists in different forms, including rape, murder and assault, online harassment, increased surveillance, impersonation, forced detention, and other digital threats (Hicks, 2013; Jamil \& Muschert, 2020; Reporters without borders, 2019; Sohal, 2020). Hence, in the past decade, journalists' killings around the world suggest that journalism is no more a safe profession and threats to journalists' safety are seriously affecting the freedom of media in many countries of the world (Jamil, 2019b). According to Committee to protect journalists (2019), 1872 journalists have been killed between 1992 and 2018, and the killers remained unidentified in the majority of cases especially in non-democratic regimes. There are countries worldwide (such as China, Egypt, Turkey, Brazil and others) - where media freedom has largely declined due to violence against journalists, their killings and imprisonment, and the climate of impunity (Reporters without borders, 2020).

Particularly, the Asia-Pacific region is the 'third-worst violator of media freedom' in the world. While thelevel of media freedom and journalists' protection is not better in the Middle East and the North African regions, the Asia-Pacific region stands out because it is 'home to the two of the top ten worst countries for journalists' killings over the past 25 years', namely: Pakistan (the worst-ranked country in 2014 in terms of journalists' killings) and India (Reporters without borders, 2019). Reports by international organizations suggest that the number of killed journalists, in Pakistan and India, is apprehensive. For example, the Committee to protect journalists' latest report reveals that 61 Pakistani and 50 Indian journalists have lost their lives in the line of their duty during this period (Committee to protect journalists, 2019). Unfortunately, the existing culture of impunity allows the perpetrators to go scot-free, and the victims do not get justice. For instance, Committee to protect journalists' Impunity index (2019) indicates that Pakistan and India rank in the top twelve of those countries that do not probe and prosecute journalists' killings and violence against them.

The abusive and repressive nature of the ruling governments and military, armed with laws that restrain journalists' freedom of expression and the freedom of media (such as Pakistan Penal Code, 1860; Pakistan's Official Secrecy Act, 1923; Defamation Ordinance, 2002; Investigation for Fair Trial Act, 2013; Pakistan Electronic Crimes Act, 2016; Indian Penal Code, 1860; India's Official Secrets Act, 1923; India's Unlawful Activities Prevention Act, 1967; Section 499 and 500 of Criminal Defamation of Indian Penal Code; 
India's Armed Forces [Special Powers] Act, 1958) have proven to be the utmost apparatus for curbing the media's and the journalists' freedoms in Pakistan and India for years. Nevertheless, what is more, alarming is the fatal safety risks that Pakistani and Indian journalists face when doing their day-to-day work. Unfortunately, now the growing concerns over the journalists' right to freedom of expression and media freedom are being replaced by their 'fear of staying alive' in the course of reporting.

Journalism scholars recognize the potential risks to journalists' lives in many countries of the world and there has been a growth in academic research within the area of safety of journalists. For instance, recently many scholars have paid attention to analyse journalists' safety issues, to mention a few studies: journalists' protection in conflict situation from practical, legal and humanitarian perspectives (Lisosky \& Henrichsen, 2011); organized crimes against journalists in Mexico (Hughes \& Marquez-Ramirez, 2017; Relly et al., 2013); typology of digital risks to journalists (Henrichsen et al., 2015); journalists' killings and physical targeting (Cottle et al., 2016); threats to journalists' safety in Kenya (George, 2016); risks to journalists in Pakistan (Ashraf \& Brooten, 2017; Bhattacharya, 2015; Jamil, 2017a, 2017b, 2018, 2019b, 2020a; Masood, 2017; Rizwan, 2014); challenges to journalists' protection in Nepal (Adhikary et al., 2016); social responsibility and protection of journalists in South Asia (Rao \& Weerasinghe, 2011); freedom of speech and expression amid rise of nationalism on India (Siddiqui, 2017); appraisal of constitutional safeguards, legal restrictions and impact of state control on journalism in India (Sohal, 2020); freedom of expression, impunity and journalists' online and offline protections (Carlsson \& Poyhatari, 2017; Jamil et al., 2020; Larry, 2017).

Despite the scholars' growing research interest to investigate threats to journalists' safety in various countries, limited studies exist that offer qualitative and comparative insights into journalists' lived experiences of safety risks in Pakistan and India, which are neighbouring countries and used to be one territory of the Indian sub-continent before the partition in 1947. Therefore, drawing on the system theory, this study aims to investigate the journalists' lived experiences of diverse safety risks in Pakistan and India. To investigate the abovementioned research objective, this study uses the qualitative methods of document reviews and in-depth interviews. Besides, this study uses thematic analysis to analyse the gathered data. Hence, this article begins with a review of literature into the system theory and the issue of the safety of journalists in Pakistan and India. Subsequently, the article explains the methodology and findings of this study. Finally, it presents the conclusion. 


\section{Literature review System theory}

The proponents of system theory posit that a system consists of interconnected parts or sub-systems. Any changes in the operation of one sub-system do affect the function of other sub-systems and on the system as a whole (Bertalanffy, 1968; Fuch \& Hofkirchner, 2009; Ziemann, 2007). The theory has been extensively used in many disciplines including sociology, political science, economics, and journalism. This study draws on Luhmann's social system theory that focuses on the interdisciplinary study of a social system. Luhmann classifies social systems at three levels: societal systems, organizations, and interaction systems. He suggests that societal systems (such as politics, religion, law, art, education, science, etc.) are interlinked with each other and are 'closed systems comprising of various fields of interaction'. He defines organizations as a 'network of decisions which reproduce themselves'. And interaction systems are 'systems that reproduce themselves on the basis of communication rather than decision making' (Seidl \& Becker 2004; Vermeer, 2006). This study posits that journalists are part of a wider social system comprising of other sub-systems (such as economic, legal, political, and cultural systems). Their protection and safety are dependent on the proper functioning and effective networking of decisions and communication among other correlated systems (especially legal and political systems). Therefore, in this study, the rationale for using the system theory is that it helps to understand the ways social systems and other linked sub-systems shape or influence the journalists' experiences of safety risks in Pakistan and India.

\section{Safety of journalists in Pakistan and India}

When looking at the case of Pakistan, the country is recognized as one of the most dangerous places for journalists in the world (Jamil, 2019b; Ricchiardi, 2012). Ironically, the Pakistani journalists deal with the dilemma of their right to safety clashing with the people's right to know (Jalil, 2014). Local journalists do not only face death threats on a regular basis, but they are also regularly monitored by the government's officials and intelligence agencies (Aslam, 2011; Jamil, 2020a). Conflict, violence, and religious extremism have made journalism one of the most difficult professions to practice in Pakistan in recent years. Consequently, the country had the highest fatality rate for journalists in the world between 2000 and 2014 (Rehmat, 2014). Jamil (2017a) suggests that the Pakistani journalists work in an unsafe institutional environment where different safety threats affect their work and the overall quality of journalism 
in the country (see also Masood, 2017). More recently, Committee to protect journalists, in its latest report, also reveals that at least 61 Pakistani journalists have been killed since 1992, suggesting the quandary of Pakistani journalists to work in an unsafe environment (Committee to protect journalists, 2019).

As far as India is concerned, in 2019 , the country was ranked at the $140^{\text {th }}$ position on The World Press Freedom Index (Reporters without borders, 2019). India is among the worst performers in protecting journalists and preserving the freedom of speech and expression in the South Asia region. According to the RSF report (2019), press freedom in India has been adversely affected by a combination of social and political factors, such as a spike in violence against journalists, state sanction of media control, police brutality, pressure from criminal groups, and political turmoil. Indian journalists, who highlight critical issues (such as state negligence and failure to maintain national security, largescale public and corporate corruption, threats to social order and public safety from power groups and political parties) are routinely targeted and silenced using draconian laws that are enshrined in the Indian Constitution and the Indian Penal Code (Sohal, 2020). The right to accessing telecommunication services and the internet has been suspended on many occasions in India, creating an information blackout for the public and the media (International federation of journalists, 2019). The Indian journalists are frequently taken into custody, detained and harassed by the police, and attacked by communal mobs for covering sensitive issues during riots and public protests (Press Trust of India, 2020). Female journalists receive threats of sexual assault, sexist slurs, and torrents of online abuse (Gudipaty, 2017). Freedom and integrity of independent media are threatened by obstructing the flow of advertising revenue and using other financial and political tactics to pressurize media and enforce self-censorship. The Indian media organizations, which are critical of the national government, are denied government advertisements, forcing them to either shut down operations or to tow the official line. Journalists, covering conflicts in Kashmir and Maoist insurgency, are at the highest risk of their lives and work under immense pressure (International federation of journalists, 2019).

These are some key facts that are mostly reported by international organizations monitoring freedom of media and journalists' protection. This study is unique given it provides qualitative insights into the issue of the safety of journalists and it unpacks the first-hand account of journalists' lived experiences of safety risks in Pakistan and India. 


\section{Methodology \\ Data collection in Pakistan}

This study has used the qualitative methods of document review and in-depth interviews (face-to-face) to investigate a research question, namely: What are the journalists' lived experiences of safety risks in Pakistan and India? Initially, different types of documents have been reviewed for this study including reports by international organizations on violence against journalists, the Constitution of Pakistan (1973), Pakistan Penal code (1860), Defamation Ordinance (2002), Wage Board Award (2013), the proposed Bill for Journalists' Safety (2016) and Harassment of Women at Workplace Act (2010).

Using purposive sampling ${ }^{2}$, a total of 30 male and female journalists from five ethnicities (i.e. Sindhi, Punjabi, Pashtu, Baluchi, and Urdu-speaking) and of religious sects (i.e. Shia and Sunni) have been interviewed to investigate their lived experiences of safety risks in Pakistan. In terms of the gender bifurcation of interviewees, the study includes 10 female and 20 male journalists. The selected number of female journalists is lesser as compared to male journalists given the male dominance in the Pakistani news media. The selected male and female journalists are of age ranging between 25 and 65 years, and they are full-time employees of Pakistan's mainstream Urdu and English languages' newspapers and television news channels that operate in Karachi. These news media organizations include six English language's newspapers (Daily Dawn, Express Tribune, The Nation, The News International, Business Recorder, and Daily Times); three Urdu language's newspapers (Daily Jang, Daily Express, and Nawa-e-Waqt); eleven Urdu language's television news channels (Geo News, Express News, SAMAA News, ARY News, AAJ News, Dunya News, Channel 92, Ab Tak News, Dawn News, News One, Pakistan Television Corporation - PTV News). The key location of data collection is Karachi; however, all selected journalists have work experience in more than one city of Pakistan.

Each journalist, in this study, has been interviewed for around one hour (i.e. 60 minutes). All interviewed journalists have been asked questions relating to their lived experiences of diverse types of safety risks that they combat while performing their routine work. Moreover, the researcher (i.e. the first author) has collected the data of this study between December 2018 and February 2019. Initially, the researcher had contacted almost 50 print and electronic media journalists in Karachi through phone calls and e-mails. Then, the researcher

${ }^{2}$ Purposive sampling refers to a type of non-probability sampling that involves selection of information-rich and reliable data sources that can efficiently answer the research question (Maxwell, 1997). 
finalized the list of participating journalists, who had agreed to give face-to-face interviews.

As far as the procedure of data collection is concerned, all questions during the interviews have been asked in Urdu-language (i.e. journalists' mother tongue in Pakistan), and then interview transcripts have been transcribed in Englishlanguage and verbatim. All participants, in this study, have been provided a project information sheet that provides information about the objectives of this study, methodology, types of research questions with examples, voluntary participation, the confidentiality of journalists' names, and their access to research findings. To ensure the privacy and safety of research participants, all interviewed Pakistani journalists have been quoted using numbers (ranging between 1 and 30).

\section{Data collection in India}

The documents reviewed, in this study, relate to safety risks for journalists in India. It includes reports by international organizations and news media organizations, statements by the Editors' Guild of India (EGI), the Constitution of India (1950), the Indian Penal Code (1860).

Following the method of purposive sampling, a total of 30 male and female journalists from seven ethnicities in India (i.e. Punjabi, Haryanavi, Himachali, Kashmiri, Bengali, Marathi, and Hindi-speaking) and four religious sects (i.e. Hinduism, Sikhism, Islam, and Jainism) have been interviewed to investigate their lived experiences of safety risks. The study includes 10 female and 20 male journalists. The selected male and female journalists are of age ranging between 25 and 65 years and are full-time employees of India's mainstream news media, including Hindi, Punjabi, Marathi, and English languages' newspapers, news magazines, news websites, and television news channels that are based in the Indian cities of Delhi, Mumbai and Chandigarh. These news media organizations include five English language newspapers (The Times of India, Hindustan Times, The Indian Express, The Hindu, and The Tribune), two Hindi language newspapers (Dainik Bhaskar, and Dainik Jagran); three Punjabi languages news television channels (News18 Punjab, ABP Sanjha and PTC News); three English language news television channels (Times Now, NDTV and CNN-TV18); two English language news magazines (Open Magazine and India Today); one Marathi language newspaper (Loksatta); two English language news website (The Print, News Laundry and UNT). The prime location of data collection is Chandigarh, Delhi, and Mumbai; however, all selected journalists have experience of working in more than one city of India. 
For this study, each journalist has been interviewed for about an hour (i.e. 60 minutes). All interviewed journalists have been provided a fact-sheet explaining the objectives of the study. Interviewees have been asked questions related to their lived experiences of diverse types of safety risks faced by them during their routine work as a journalist. The data has been collected between November 2019 and March 2020. A total of 45 journalists were initially contacted by the researcher (i.e. the second author) through phone calls and emails. Then finally 30 of them were selected based on their availability and relevance to the study. All questions during the interviews have been asked in English, Hindi, and Punjabi, based on the language fluency of the interviewees. The final transcripts of the interviews have been transcribed in English and verbatim. All the participants have been provided a project information sheet that explicitly mentions the objectives of this study, methodology, types of research questions with examples, voluntary participation, the confidentiality of journalists' names, and access to research findings. To ensure the privacy and safety of research participants, all interviewed Indian journalists have been quoted using numbers (ranging between 31 and 60).

\section{Data analysis}

This study uses thematic analysis to analyse the gathered data under two key themes that have emerged inductively from the interview data, namely: (i) journalists' lived experience of safety risks in Pakistan; (ii) journalists' lived experiences of safety risks in India. To present the study's findings clearly under different sub-themes, the thematic analysis of qualitative data (i.e. in-depth interviews) has been corroborated with the semi-quantification analysis, which means the use of quantitative estimations within the journalists' responses to each research question and in different sub-themes (Maxwell, 2010). The sub-themes have been identified based on the prevalence of keywords in the journalists' responses to each research question. The prevalence of sub-themes (i.e. indicated with p), substantiated with quantitative estimations (See Tables 1 and 2), has been decided based on the number of journalists' responses in each sub-theme (see also Jamil, 2020b, 2020c).

\section{Data validity}

Data triangulation has been used in this study. Triangulation in research refers to the use of two or more research methodologies or theories to investigate and answer a research objective (Denzin, 1970; Flick, 2000). Thus, qualitative data from document review and in-depth interviews have been used to interpret, articulate and validate the findings. 
There are a couple of challenges that both researchers faced during data collection in Pakistan and India. Firstly, it was hard to engage female journalists in both countries due to male dominance in the journalism profession. Therefore, both researchers from Pakistan and India had to compromise with the gender gap in sampled journalists. Secondly, both researchers had to face challenges to schedule interviews with journalists in repeated slots due to the cancellation of scheduled interviews on several occasions both in Pakistan and India. Most interview cancellations occurred due to routine issues with journalists. Thirdly, the location of data collection was restricted only to the major cities in Pakistan and India (i.e. Karachi, Delhi, Mumbai, and Chandigarh) to reduce the travel cost incurred by both researchers. Moreover, analysing a large set of data from both Pakistan and India was challenging for both researchers given that the data had revealed commonalties of safety risks faced by journalists more as compared to any rare experiences distinct to their respective countries. The experiences of risks and threats to safety shared by the respondents were difficult to isolate and categorize into independent categories due to the interdependence of these occurrences. The experiences appeared to result from systemic issues that codepend on each other, and many of these systemic issues are universal and are present in systems of similar nature and context.

\section{Findings}

\section{Journalists' lived experiences of safety risks in Pakistan}

Over the last decade, journalists' safety and protection have emerged as serious issues in Pakistan. According to the latest report, published in Daily Dawn, around 33 Pakistani journalists have been killed during the past six years (Dawn, 2019). This study also reveals that Pakistani journalists, either from print or electronic media, face diverse threats countrywide regardless of their ethnicities and specific beats. The most pressing concern, raised by the interviewed male and female journalists, is regarding their physical safety. This study finds that Pakistani journalists have to employ self-censorship to avoid consequences such as life threats, kidnapping, attacks, and even murder. Table 1, below, explains the diverse safety risks faced by Pakistani journalists. 
Table 1

Journalists' lived experiences of safety risks in Pakistan

\begin{tabular}{|c|c|c|c|}
\hline \multirow[b]{2}{*}{ Sub-themes } & \multicolumn{3}{|c|}{ In-depth interview } \\
\hline & $\begin{array}{c}\text { Number of } \\
\text { journalists } \\
(n=30)\end{array}$ & $\begin{array}{c}\begin{array}{c}\text { Number } \\
\text { of female } \\
\text { journalists }\end{array} \\
(n=10)\end{array}$ & $\begin{array}{c}\begin{array}{c}\text { Number } \\
\text { of male } \\
\text { journalists } \\
(n=20)\end{array} \\
\end{array}$ \\
\hline $\begin{array}{l}\text { Sub-theme } 1(\mathrm{P}=29) \\
\text { Physical risks (i.e. killing, } \\
\text { kidnapping, attack, assault, injury, } \\
\text { and physical surveillance) }\end{array}$ & $\begin{array}{c}29 \\
\text { out of } 30\end{array}$ & $\begin{array}{c}10 \\
\text { out of } 10\end{array}$ & $\begin{array}{c}19 \\
\text { out of } 20\end{array}$ \\
\hline $\begin{array}{l}\text { Sub-theme } 2(\mathrm{P}=29) \\
\text { Psychological risks (i.e. anxiety; } \\
\text { depression; feelings of fear and } \\
\text { pressure and frustration) }\end{array}$ & $\begin{array}{c}29 \\
\text { out of } 30\end{array}$ & $\begin{array}{c}9 \\
\text { out of } 10\end{array}$ & $\begin{array}{c}20 \\
\text { out of } 20\end{array}$ \\
\hline $\begin{array}{l}\text { Sub-theme } 3(\mathrm{P}=30) \\
\text { Financial risks (i.e. forced job } \\
\text { termination, non-payment of } \\
\text { salary, and low pay scales) }\end{array}$ & $\begin{array}{c}30 \\
\text { out of } 30\end{array}$ & $\begin{array}{c}10 \\
\text { out of } 10\end{array}$ & $\begin{array}{c}20 \\
\text { out } 20\end{array}$ \\
\hline $\begin{array}{c}\text { Sub-theme } 4(\mathrm{P}=21) \\
\text { Digital risks (i.e. digital } \\
\text { surveillance of journalists' } \\
\text { communication; threats through } \\
\text { mobile phones, e-mail, and social } \\
\text { media; e-mail and social media } \\
\text { accounts' hacking; abusive emails } \\
\text { and social media troll) }\end{array}$ & $\begin{array}{c}21 \\
\text { out of } 30\end{array}$ & $\begin{array}{c}7 \\
\text { out of } 10\end{array}$ & $\begin{array}{c}14 \\
\text { out of } 20\end{array}$ \\
\hline $\begin{array}{c}\text { Sub-theme } 5(\mathrm{P}=17) \\
\text { Gender-specific risks (i.e. rape, } \\
\text { sexual harassment, offline and } \\
\text { online use of sexist slurs and } \\
\text { blackmailing from opposite gender) }\end{array}$ & $\begin{array}{c}17 \\
\text { out of } 30\end{array}$ & $\begin{array}{c}10 \\
\text { out of } 10\end{array}$ & $\begin{array}{c}7 \\
\text { out of } 20\end{array}$ \\
\hline $\begin{array}{c}\text { Sub-theme } 6(\mathrm{P}=9) \\
\text { Topic-specific risk }\end{array}$ & $\begin{array}{c}9 \\
\text { out of } 30\end{array}$ & $\begin{array}{c}2 \\
\text { out of } 10\end{array}$ & $\begin{array}{c}7 \\
\text { out of } 10\end{array}$ \\
\hline
\end{tabular}




\begin{tabular}{|c|c|c|c|}
\hline $\begin{array}{c}\text { Sub-theme 7 }(\mathrm{P}=25) \\
\text { Public risks }\end{array}$ & $\begin{array}{c}25 \\
\text { out of } 30\end{array}$ & $\begin{array}{c}7 \\
\text { out of } 10\end{array}$ & $\begin{array}{c}18 \\
\text { out of } 10\end{array}$ \\
\hline $\begin{array}{c}\text { Sub-theme 8 }(\mathrm{P}=21) \\
\begin{array}{c}\text { Legal risks (i.e. punitive laws, } \\
\text { imprisonment, risk of legal suit, } \\
\text { extrajudicial or encounter killing } \\
\text { and arbitrary detention) }\end{array}\end{array}$ & out of 30 & 4 out of 10 & 17 \\
out of 20 \\
\hline
\end{tabular}

This study highlights that mostly investigative journalists are attacked, and it is always difficult to accuse any particular group or institution directly. For instance, one interviewee highlights that 'in 2011, there were several incidents of target killings in Karachi' (Interviewee number 5). When talking about physical and other risks to journalists, the director news of a local television news channel states:

We receive life's threat and regardless of our ethnicity. A journalist, from any ethnicity, can be attacked and people are doing journalism even in this situation. Previously, the perception of threat was different. A journalist's family used to be aware that police has picked him, in the case of his arrest. Today, the difficulty is that even a journalist's family does not know - who has picked him? Police or who else? And journalists' families wait for them for weeks (Interviewee number 15).

The above-mentioned cases are only a few examples of violence and attacks against journalists in Karachi. In recent years, safety threats have spawned serious challenges for the working journalists across Pakistan, especially in the conflict areas of Baluchistan and Khyber Phakhtunistan. Interview data reveals that journalists particularly confront severe threats from militants in the conflict zones of Baluchistan and Khyber Phakhtunistan. In this regard, Interviewee number 6 mentions that 'journalists face the threats of militants in conflict zones and while talking about controversial issues such as Pakistan's Blasphemy Laws'. Another interviewed journalist particularly talks about threats in the conflict zones of Pakistan. He unpacks:

Journalists from Karachi or Islamabad or Lahore get astounded, when they hear stories from the journalists of Khyber Phaktunistan and Federally Administered Tribal Area (FATA), how much they are sustaining pressure. Many things do not come on screen. There is a huge difference between the situation of FATA and Karachi (Interviewee number 29). 
An information barrier has also been created due to the fearful environment of Pakistan and life's risks in conflict zones. Ironically, media organizations have to compromise on the quality of information from these areas. For instance, one male interviewee reveals:

Let us take the example of Baluchistan. My reporters cannot go there. They are worried about their safety because they can be kidnapped or shot either by militants or the government. Personally, as an editor, I feel that there are a lot of issues, which can be reported but these are never reported in the media due to safety threats. Another example is Federally Administered Tribal Areas (FATA). Our journalists cannot go as militants there. So, we have to rely on second-hand information (Interviewee number 13).

This study manifests that some Pakistani areas including Khyber Pakhtunkhwa (KP), FATA, and Balochistan are the most dangerous for working journalists as violence has been on a rise in these areas for the past several years, making their job risky and difficult (see also Ashraf \& Brooten 2017; Jamil, 2017a, 2015a, 2015b). 'Many journalists in FATA and Balochistan have discontinued reporting due to their increased vulnerability to fatal risks in these areas, those who have continued their jobs, are reporting under severe fear and pressure of militants, army, and intelligence agencies', reveals the editor of an English language newspaper (Interviewee number 2). Unfortunately, the incidents of violence against journalists do not only occur in Balochistan, but violent incidents and journalists' killings are common countrywide. One of the reporters of a local television news channels in Karachi, who has worked in FATA and Khyber Pakhtunkhwa areas as well, reveals:

From 2008-2012, I was assigned to cover Taliban activities along with the areas of North and South Waziristan, Khyber Agency, and other tribal areas where they have a stronghold. I used to receive death and kidnapping threats almost every day. Twice, I was attacked and I had suffered severe injuries to the extent that I could not continue work for weeks. My organization did not provide complete medical expenditure; and therefore, that is another traumatic story about how I managed my treatment (Interviewee number 13).

In the light of system theory, these findings indicate that the Pakistani media organizations and the government both lack organizational and institutional support systems to ensure the protection and safety of journalists when they cover conflict areas in the country. The organizational support system means a comprehensive briefing about the conflict and conflict area, safety training on survival techniques, provision of safety equipment (such as bulletproof jackets), provision of life and medical insurance - in the case of death and injury respectively (Jamil, 2019a, 2019b). Indeed, the organizational support system 
should not just focus on working journalists, but also consider the protection of photojournalists, cameramen and other crew that work in conflict zones. In this regard, a senior male political journalist shares one of his experiences:

In 2006, I was covering a story near the Afghan border and my cameraman got injured with the bullet of a law enforcement agency personnel. I had a narrow escape too. Later, I came to know that the driver of my van had lost his life and the cameraman had suffered disability due to injury in his leg. Both, either cameraman or the driver, did not receive any compensation from their organization. Now the provincial journalists' unions have developed safety funds for the financial aid of journalists (Interviewee number 13).

The dilemma of journalists' safety not only necessitates ensuring their safe access to the conflict areas in Pakistan but also improving the level of safety provided to them by the local law enforcement agencies and media organizations. For example, interviewee number 5 mentions the negligence of Pakistani media organizations towards journalists' safety and says that 'big television news channels provide blood-proof jackets to their reporters to undertake their work. Small television news channels do not provide any security to reporters, drivers and cameramen'. Interview data reveals that the journalists do not merely face physical risks, but they also confront substantial financial risks in the form of low pay scales, forced job terminations and non-payment of salaries up to several months. Some journalists (see Table 1: Sub-theme 3) mention that they are compelled to manipulate the information to serve the vested interests of their owners and for their financial protection. For example, according to a male interviewee:

Chances of my job termination can increase if I do any story that hurts the vested interests of my owner and editor. Organisation tries to present the information after moulding it in a way that reality is contradictory to the given information (Interviewee number 21).

Likewise, an interviewed female journalist highlights the ways physical and financial risks, and social class stratification, are resulting in psychological threats to journalists (see Table 1: Sub-theme 2). She says:

During 13 years of my career, I have changed jobs thrice. Once I was terminated due to the downsizing of staff in my news organization. I got a job after a struggle of seven months. This was my first experience of depression as a journalist. Then in my two jobs, I was never paid a salary on-time, which used to be stressful (Interviewee number 29).

Another female journalist, from an English language newspaper, explains how gender-specific threats affect the mental health of female journalists in Pakistan. She states: 
Female journalists suffer psychologically more because they are not only targeted as a journalist but also as a woman. Sexual harassment is common in the Pakistani news media and especially in television news channels. Then we face sexist slurs and social media trolling. It is not just the fear of life that affects us. We are suffering many psychological issues that range from depression, anxiety, and frustration (Interviewee number 10).

This implies that the Pakistani female journalists experience sexual harassment and abuse physically and online both, resulting in greater chances of gender-specific risks to them as compared to male journalists. In addition to physical, psychological, and financial risks, the Pakistani male and female journalists confront digital risks in various forms (see Table 1: Sub-theme 4). Thus, a female news producer highlights:

With the online threats to journalists, I feel that the violence experienced by many female journalists has simply moved into cyberspace without changing its basic nature. I have experienced verbal abuse, social media troll, and even threats of acid violence once because I used to be on the production team of a political talk show at a leading Pakistani news channel. Many of my male colleagues have suffered from e-mail and social media accounts' hacking (Interviewee number 3).

Studies have shown that perpetrators of online abuse against journalists are armed with simple, less expensive, and faster means of attacking journalists, such as a smart device with an internet connection is enough for perpetrators to attack journalists online. Therefore, digitization of the journalism practice has heightened the vulnerability of journalists to online attacks (Antonijevic, 2016). Different social media strategies are used by different actors to attack journalists, as well as discredit their stories (Ferrier, 2018). But for Pakistani journalists, threats are much diversified. For example, several interviewed journalists also highlight that they are suffering from topic-specific and public risks too (see Table 1: Sub-themes 6 and 7). For example, an interviewed male journalist reveals:

Pakistan is a conservative country. One cannot write openly here about certain social issues (such as homosexuals and LGBTs); religious matters; issues of national security, government, army, and judiciary. We may suffer from life risks because of writing on these issues, but more than that it causes fear and pressure of any possible harm to our lives and our families. The public has also emerged as a big threat because people do attack journalists. So, at times psychological threats kill us more than physical threats (Interviewee number 16).

Considering the pressing need of protecting journalists psychologically, in 2014, Peshawar University's Departments of Psychology and Journalism 
have established a 'Competence and Trauma Centre' in collaboration with Deutsche Welle Akademie, which is a German media company. However, the establishment of more counselling centers is required in other provinces of Pakistan - where journalists can consult for free on their psychological and emotional problems. Moreover, several interviewed journalists express their apprehensions regarding the legal system of Pakistan, which is fostering legal risks and the culture of impunity in the country. According to a male interviewee:

Media organizations and journalist's unions do not come forward to provide legal assistance for longer periods of court proceedings $\langle\ldots\rangle$. We do have the right to a fair trial on paper. But the Article 10 (A) of the Constitution does not ensure the elements of transparency, decorum, and judicial propriety that are the basic ingredients of a fair trial (Interviewee number 16).

The Pakistani journalists' feedbacks unpack that blasphemy is a crucial religious issue in the country. The Blasphemy laws, under Pakistan Penal Code (1860), restrict Pakistani citizens from any sort of derogatory speech against Islam and the Holy Prophet (peace be upon him). Therefore, journalists should be very careful in their religious speech to avoid any legal action and the public's reaction in general. This study substantiates these facts. For example, interviewee number 30 states:

Blasphemy is a very sensitive issue here. We are very sensitive towards religious symbols and icons. When we write Holy Prophet, we do write '(peace be upon him)' or write 'Holy Qur'an'. So, these are the things that journalists have to do because they do not want hundreds of people coming and torturing their offices (Interviewee number 30).

Thus, drawing on the system theory, this study reveals that Pakistan's journalists are working in complex social, political, and legal systems that lack proper functioning, transparency, values, and propriety. This indicates that the scope of safe journalism is limited in Pakistan until effective initiatives and reforms are made at various levels.

\section{Journalists' lived experiences of safety risks in India}

This study reveals that Indian journalists face multiple threats and risks as part of their routine job, which is quite similar to the case of Pakistani journalists. Financial instability, job insecurity, public risks, and threats to physical safety are among the most commonly experienced issues, which induce psychological risks and emotional distress. Table 2 below highlights the risks experienced by the Indian journalists. 
Table 2

Journalists' lived experiences of safety risks in India

\begin{tabular}{|c|c|c|c|}
\hline \multirow[b]{2}{*}{ Sub-themes } & \multicolumn{3}{|c|}{ In-depth interview } \\
\hline & $\begin{array}{c}\text { Number } \\
\text { of } \\
\text { journalists } \\
(\mathrm{n}=30)\end{array}$ & $\begin{array}{c}\text { Number } \\
\text { of female } \\
\text { journalists } \\
(n=10)\end{array}$ & $\begin{array}{c}\text { Number } \\
\text { of male } \\
\text { journalists } \\
(n=20)\end{array}$ \\
\hline $\begin{array}{c}\text { Sub-theme } 1(\mathrm{P}=29) \\
\text { Physical risks (i.e. killing, kidnapping, } \\
\text { attack, assault, injury, and physical } \\
\text { surveillance) }\end{array}$ & $\begin{array}{c}29 \\
\text { out of } 30\end{array}$ & $\begin{array}{c}9 \\
\text { out of } 10\end{array}$ & $\begin{array}{c}20 \\
\text { out of } 20\end{array}$ \\
\hline $\begin{array}{c}\text { Sub-theme } 2(\mathrm{P}=30) \\
\text { Psychological risks (i.e. anxiety; depression; } \\
\text { feelings of fear and pressure and } \\
\text { frustration) }\end{array}$ & $\begin{array}{c}30 \\
\text { out of } 30\end{array}$ & $\begin{array}{c}10 \\
\text { out of } 10\end{array}$ & $\begin{array}{c}20 \\
\text { out of } 20\end{array}$ \\
\hline $\begin{array}{l}\text { Sub-theme } 3(\mathrm{P}=30) \\
\text { Financial risks (i.e. forced job termination, } \\
\text { non-payment of salary, and low pay scales) }\end{array}$ & $\begin{array}{c}30 \\
\text { out of } 30\end{array}$ & $\begin{array}{c}10 \\
\text { out of } 10\end{array}$ & $\begin{array}{c}20 \\
\text { out } 20\end{array}$ \\
\hline $\begin{array}{l}\text { Sub-theme 4 }(\mathrm{P}=29) \\
\text { Digital risks (i.e. digital surveillance of } \\
\text { journalists' communication; threats through } \\
\text { mobile phones, e-mail, and social media; } \\
\text { e-mail and social media accounts' hacking; } \\
\text { abusive emails and social media troll) }\end{array}$ & $\begin{array}{c}29 \\
\text { out of } 30\end{array}$ & $\begin{array}{c}9 \\
\text { out of } 10\end{array}$ & $\begin{array}{c}20 \\
\text { out of } 20\end{array}$ \\
\hline $\begin{array}{c}\text { Sub-theme } 5(\mathrm{P}=15) \\
\text { Gender-specific risks (i.e. rape, sexual } \\
\text { harassment, offline and online use of } \\
\text { sexist slurs and blackmailing from opposite } \\
\text { gender) }\end{array}$ & $\begin{array}{c}15 \\
\text { out of } 30\end{array}$ & $\begin{array}{c}10 \\
\text { out of } 10\end{array}$ & $\begin{array}{c}5 \\
\text { out of } 20\end{array}$ \\
\hline $\begin{array}{c}\text { Sub-theme } 6(\mathrm{P}=22) \\
\text { Topic-specific risk } \\
\end{array}$ & $\begin{array}{c}22 \\
\text { out of } 30\end{array}$ & 7 out of 10 & $\begin{array}{c}15 \\
\text { out of } 20\end{array}$ \\
\hline $\begin{array}{c}\text { Sub-theme } 7(\mathrm{P}=20) \\
\text { Public risks }\end{array}$ & $\begin{array}{c}20 \\
\text { out of } 30\end{array}$ & $\begin{array}{c}10 \\
\text { out of } 10\end{array}$ & $\begin{array}{c}10 \\
\text { out of } 10\end{array}$ \\
\hline $\begin{array}{c}\text { Sub-theme } 8(\mathrm{P}=23) \\
\text { Legal risks (i.e. punitive laws, } \\
\text { imprisonment, risk of legal suit, } \\
\text { extrajudicial or encounter killing and } \\
\text { arbitrary detention) }\end{array}$ & $\begin{array}{c}23 \\
\text { out of } 30\end{array}$ & $\begin{array}{c}6 \\
\text { out of } 10\end{array}$ & $\begin{array}{c}17 \\
\text { out of } 20\end{array}$ \\
\hline
\end{tabular}


This study highlights that financial risks, which include situations leading to job insecurity, low wages, job loss, deferral in salary or non-payment of salary, among others, are experienced by all Indian journalists, irrespective of their ethnic origin, specialization, organizational association, gender, and years of experience (See Table 2: Sub-theme 2). A male journalist working for an English language newspaper in North India says that 'financial insecurity begins early in the career of a journalist as the entry-level wages are low and increments are inconsistent with the work profiles and experience of journalists, which makes several emerging journalists reconsider journalism as a long-term profession' (Interviewee number 33).

Issues related to ethical violations in Indian journalism are often linked to the low wages and poor financial conditions of the journalists, which makes them vulnerable to accepting cash, gifts, and favours, in return for publishing planted news (Shaw, 2015). This means that the Indian and the Pakistani journalists both are attracted to corruption and unethical conduct because of their financial crises. For example, a female interviewee reveals:

I know several colleagues in my office who have ultimately resorted to accepting bribes or favours to meet their financial needs. I have been offered money on a few occasions by political parties, and they try to normalize it by saying that they know that journalists are not paid well and that everyone at one point takes it (Interviewee number 36).

While financial insecurity and low wages are associated with unethical reporting in media, and interviewed journalist mentions, 'at times I publish insignificant stories just to please my source. These stories mean little to the average public, but my sources have some micro-level vested interest. So, I publish planted stories too', says a crime reporter from a leading English language newspaper in India (Interviewee number 41). Comparing the cases of Pakistan and India, the Pakistani journalists are usually forced to publish and broadcast the planted stories being under pressure of the government, intelligence agencies, and militant or religious groups. In both cases, the Pakistani and the Indian journalists are the victims of fear and pressure.

Furthermore, all the Indian interviewed journalists unpack that they have felt threatened and unsafe in public on several occasions while carrying-out their routine work. Journalists are often confronted with situations where there is little scope for peaceful negotiations with the public. At times, these situations lead to the assault on journalists. Like the Pakistani journalists' experience, the public risks and physical risks are routinely experienced by the Indian journalists working in conflict zones or troubled areas or by beat reports while covering sensitive news stories or facing an angry mob (see Table 2: Sub-themes 1 and 7). 
Interestingly, the Indian journalists face public risks even while covering seemingly peaceful situations, which is not the situation faced by the Pakistani interviewed journalists. For example, one of the male Indian journalists says:

The public risk while covering a story can be sensed, but I know that I can be targeted after the publication of a news story and this attack can come in any form. Even though journalists write stories in the public interest, there is always a political party that feels that they have been targeted or wronged. It can be a challenge to deal with them (Interviewee number 43).

In addition to the physical risks, Indian journalists do experience considerable digital risks. The digital risks include snooping, trolling, or abusing on social media, digital surveillance, and threats using phones, social media, and emails, among others. Digital media is also an easy tool to harass as the identity of the abuser can be easily masked. This implies that the nature of digital risks faced by the Indian journalists is quite the same as faced by the Pakistani journalists (see Table 1: Sub-theme 4; Table 2: Sub-theme 4). Concerning this, one of the male journalists, working as a reporter for an English language TV news channel says, 'online trolling against journalists has become very common. Journalists are not only trolled for the stories that they publish, but they are also targeted for their personal opinion. I have experienced very disturbing online abuses personally' (Interviewee number 38).

Similar to the Pakistani journalists' experience, the interviewed Indian journalists also reveal that financial insecurity, everyday risks, and physical risks as the biggest cause of emotional and psychological distress, which is experienced by all the interviewees at different times in their careers. One of the male journalists working with a TV news channel highlights:

In the early years of my career, I used to often remain depressed thinking about my financial situation. My family did not support my choice of being a journalist, so I could not even share my worries with them. There have been several moments that have distressed me, being attacked and being harassed by the public were common reasons besides my depressed state of mind. I am not sure whether I have learned to deal with stress and whether I have accepted it as part of my profession. What I know is that it has taken a toll on my mental health (Interviewee number 44).

From a gender perspective, India is among the most unsafe places to be a woman. Society has deep-rooted patriarchy that makes it difficult for women to break the glass ceiling without sacrificing family life, risking their safety and public image (Dewan, 2018). The study reveals that gender-based risks are also 
experienced by the female interviewed journalists. While a few male journalists reveal that they have been sexually harassed, all interviewed female journalists unpack that they have experienced sexual harassment and have been at risk of sexual assault at their external workplaces and within organizations. One of the female journalists, who work for a newspaper, says:

Sexual harassment is an everyday thing for me. It begins in my office, where obscene language and sexist comments are commonly used, and inappropriate physical contact is a normal routine activity. If female journalists complain about such behaviour, they are considered meek and unfit for the job of a muckraker. I had once complained to my senior about a sexual harasser in my office, I was calmly told to ignore the man as he was a good reporter (Interviewee number 53).

Another female journalist, working with a vernacular newspaper, reveals her experience of facing sexual harassment at work. She states:

I cover the political and crime beat, so I often enter very male-dominated premises to carry out my newsgathering routines. I am seen as a sexual object and I hear sexual comments almost every day by different people. There have been incidents where senior police officials have commented on my body parts publicly. A female journalist is viewed as someone willing to comprise her dignity for a news story or a few favours. I get a lot of unwanted attention, which affects not only my work but also my mental health (Interviewee number 54).

These findings are not unique to India because most Pakistani interviewed female journalists in this study and a recent gender specific study in Pakistan highlight that the Pakistani women journalists find it difficult to work as a journalist by sexual harassment and verbal abuse both outside and within their media organizations (Jamil, 2020e). Unfortunately, laws protecting female journalists from sexual harassment in both India and Pakistan, are not effective enough to facilitate a safe working environment for them (Sohal, 2021). Like the Pakistani legal system, the Indian legal framework neither protects journalists from diverse types of safety threats and nor it is strong enough to combat the prevailing culture of impunity to crimes and violence against journalists.

\section{Discussion}

The media, in both India and Pakistan, have been crucial to the movements to attain independence from the British Empire in 1947. News media, in South Asian society, have always been a battlefield, chained up to colonial legacies of 
being used as an instrument for nation-building versus operating as a watchdog for the state authorities. International organizations, monitoring freedom of the press and journalists' safety, recurrently suggest that the state of media and journalists' safety have curtailed in both countries (Reporters without borders, 2020). Interviewed journalists' feedbacks, in Pakistan and India, substantially echo this fact. According to an interviewed Pakistani journalist:

I do not see much difference between the situations of Pakistani and Indian journalists. We share a common political history and similarities in our news media ecology $\langle\ldots\rangle$. We experience similar nature of threats to our physical, psychological, financial, legal, and digital safeties. Unfortunately, the level of impunity to a crime against journalists is also more or less similar to a lack of an effective regulatory and judicial system that can prosecute crimes against journalists fairly and within due course. Overall, we are all in the same boat. The distinct aspect of Pakistan is that now the country is witnessing a decline in the number of journalists' killings, but the state of media freedom has drastically declined due to in-direct pressures from the government in the forms of digital censorship, digital surveillance, and frequent internet shutdown, which ultimately impinge on journalists' routine (Interviewee number 5).

When talking about digital mass surveillance as a threat to journalists' safety, a Pakistani journalist states:

I do not say that the situation in India is better than in our country in terms of journalists' safety. But digital surveillance of journalists and internet censorship have both appeared as a potential threat to the physical and digital safeties of Pakistani journalists, as well as a threat to their right to freedom of expression. Probably, the level of journalists' self-censorship is higher in Pakistan as compared to India (Interviewee number 9).

A recent report, released by the Human Rights Outlook (2019), reveals that nearly half of the world's population (i.e. 3.38 billion or 46 percent) lives in countries where freedom of speech is waning, and about 28 of these countries have authoritative regimes (Maplecroft, 2019). The report also highlights specific highrisk nations - where the journalists' protection, their sources' safety, and privacy are being curtailed and digital risks are increasing. These countries are also have been marked at extreme risk for human rights violations, suppression of speech, and free press. Such indices highlight the interconnected nature of oppressive and anti-democratic trends within countries. Suppression of the freedom of speech and expression, and violation of journalists' right to report factually and safely appear to be occurring within the same systems where 'strongmen 
authoritative regimes', a surge in hyper-nationalism and media censorship are thriving.

With such a large population of the world under state control or experiencing oppression of free speech, there is an imminent threat to democratic values at a global level. Thus, in a globalized economy, the freedom of speech and right to privacy directly impact technology and media companies, and erosion of these democratic rights among a significant population of the globe threatens the rule of law and social justice beyond borders. For example, social media company Twitter recently warned that it is concerned about the safety of its staff in India (Ellis-Petersen, 2021). The Indian government had asked the social media platform to remove over 1000 accounts related to a recent farmers' protest against new agricultural laws in India. The Indian government stated that these accounts were spreading propaganda and misinformation. When Twitter refused to take down these accounts, citing the importance of the flow of communication, the Indian government threatened fines and imprisonment up to 7 years for Twitter's staff in India by issuing an order under the country's Information and Technology Act that permits government's action in cases where public order is disturbed via social media or technology.

The Pakistani government's attempts to censor the news stories and the Internet have also drawn strong reactions from the country's journalists, as well as the Internet companies including Facebook, Google, and Twitter. Internet companies have threatened to stop their services to Pakistan if digital censorship is enforced, because of which access to sources of information and democratic channels of communication are under existential risk (Goel \& Masood, 2020). 'Earlier we were subjected to censorship offline, now it is happening online. At least social media companies can express their concerns. We are simply dumb watchdogs', says a Pakistani journalist expressing his grievance over news censorship (Interviewee number 6). Unfortunately, journalistic communities in India and Pakistan, are not empowered to urge their respective governments to respect their rights to operate freely and safely.

Both Pakistan and India are the two nuclear-armed belligerent neighbours in South Asia, a free and independent press is also required to maintain peace among the two nations and in the region. A free and independent press of a country keeps the state in check and tries to hold it accountable for internal and external peace and security. A state-controlled and censored media, as seen in cases of countries like Rwanda, Somalia, and the Balkans, instils insecurity of the other in the minds of the public, and often mongers for war and retaliation 
to favour nationalist and political agenda, while reneging the internationally acceptable routes of diplomacy and dialogue. This study highlights the risks faced by journalists covering conflict zones in Pakistan and India, illustrating the attempt to silence the press by state and non-state actors. Kashmir and Balochistan, which are a bone of contention between India and Pakistan, are the two most dangerous conflict zones for journalists and report a high violation of human rights. Over the last few years, the rise of nationalism in both countries has derailed the peace process between the two. State and non-state actors, with vested interests in the conflict, have used state-regulated and corporateowned media to create a media frenzy against the other nation. Moderated voices, factual reporting, and independent journalism on mainstream or internet are waning under fear and risk to life and livelihood of the media workers.

Exploring the lived experiences of risks and threats to journalists in Pakistan and India, this study attempts to bring the attention of the global scholarly community to the fragile state of democratic institutions in the Asia-Pacific region that is significant in terms of geopolitics, international trade, and global economy. Pakistan is also a major non-NATO ally, while India pledges to several United Nations Peace Keeping missions and conflict resolution efforts in the broader region. The violation of the human rights of journalists and the waning of the freedom of the press in the region is a matter of immediate attention. Therefore, efforts should be made to strengthen democratic institutions like the judiciary and the legislature, and free and safe space for the exchange of ideas and information, akin to the concept of the internet, should be cultivated for peace and security within the two nations and globally.

\section{Conclusion}

The analyses of journalists' lived experiences of safety risks, in Pakistan and India, reveal a stark systemic failure to protect journalists and safeguard free speech in these two countries. Journalism practice is part of a larger system that is interconnected with social, economic, and political systems (Jamil et al., 2020) Political and economic instabilities, in these two low-income countries, are responsible for widespread corruption that discourages ethical practice of journalism. Culture of impunity and state sanction of press control endangers the life of investigative journalists in both countries. The conflict zones, in Pakistan and India, are hotspots of attacks against journalists and are rife with human rights violations against civilians and press workers. The absence of strong protective laws for media workers, and a lack of agency within the media, have 
not only encouraged unethical journalism but also compelled several financially strained and socially ostracised journalists to tow the official line and avoid critical reporting of controversial issues.

The prevailing threat of terrorism in the South Asia region, along with the rise of nationalism, conservatism, and communalism in politics, has expunged liberal thought from the national discourse threatening all democratic institutions, especially the press, and the freedom of speech and expression. The study also reveals the presence of a class system among Pakistani and Indian journalists. As a result of structural inequalities within the social and economic systems of these countries, journalists working with the regional, local, or vernacular media; the female journalists; the journalists belonging to the minority community of journalists belonging to low-income or socially backward families are more vulnerable to threats and risks.

Given the system-induced multiple threats and risks faced by journalists in Pakistan and India, a systemic approach is recommended to safeguard the press and press workers. The analysis of lived experiences highlights a need for a stronger legal framework and protection mechanism for journalists against gender-based, physical, and public risks. The financial risks faced by journalists should be addressed with standards prescribed by labour laws in the industry and corporate sector with an added provision of enhanced coverage in personal and health insurance schemes. Media organizations, in both countries, should develop organizational support systems to protect journalists physically, financially and legally; and to train their staff in essential transferable skills to combat offline and online threats (see also Jamil, 2020d; Jamil \& AppiahAdjei, 2020b). Finally, governments in both countries, need to incorporate their supportive roles to develop a robust national system to buttress journalists' protection using a multi-stakeholder approach, which means developing efforts together with individual journalists, media organizations, and journalists' unions.

\section{References}

33 journalists killed in Pakistan in past six years: Report. Dawn, $1^{\text {st }}$ November, 2019. Available from: https://www.dawn.com/news/1514131

ADHIKARY, N. \& DATT, L. (2016). Supporting safety of journalists in Nepal: UNESCO database. Available from: http://unesdoc.unesco.org/images/0024/ 002456/245666e.pdf

AGARWAL, S. \& MAMDAVIA, M. (2019). WhatsApp confirms Indian journalists and activities targeted in hack. The Economic Times, 31st October, 2019. Available 
from: https://economictimes.indiatimes.com/tech/internet/whatsapp-confirmsindian-journalists-and-activists-targeted-in-hack/articleshow/71833170.cms

ANTONIJEVIC, Z. (2016). The media cannot be truly free if women voices are silenced. Available from: https://www.osce.org/fom/220411?download=true

ASHRAF, I. \& BROOTEN, L. (2017). Tribal journalists under fire. Threats, impunity and decision making in reporting on conflict in Pakistan. In: U. Carlsson \& P. Reeta, The assault on journalism. Building knowledge to protect freedom of expression, Sweden, Nordicom, University of Gothenburg, pp. 147-158.

ASLAM, R. (2011a). From hope to challenge. Media Development, WACC, LVVIII (2), pp. 2-8.

ASLAM, R. (2011b). Peace journalism: A paradigm shift in traditional media approach. Pacific Journalism Review, 17(1), pp. 113-134.

ASLAM, R. (2010). Perspectives on conflict resolution and journalistic training. In: R. L. Keeble, J. Tulloch, \& F. Zollman, Peace journalism, war and conflict resolution, London, UK, Peter Lang, pp. 335-352.

BERTALANFFY, L. (1968). General system theory: Foundations, development, applications. New York, George Braziller.

BETIGERI, A. (2019). The bad news for media in India. Available from: https:// www.lowyinstitute.org/the-interpreter/bad-news-press-freedom-india

BHATTACHARYA, S. (2015). Violence: A bane for Pakistani media. Journal of the International Relations and Affairs Group, 5(2), pp. 228-248.

CARLSSON, U. \& POYHATRI, R. (2017). Assault on journalism. Sweden, Nordicom, The University of Gothenburg Press.

Committee to protect journalists (2019). Journalists killed between 1992 and 2019/motive confirmed. Available from: https://cpj.org/data/killed/ ?status $=$ Killed \&motive Confirmed\%5B\%5D = Confirmed\&type $\% 5 B \% 5 \mathrm{D}=$ Journali st\&start_year=1992\&end_year=2020\&group_by=year

Committee to protect journalists (2019). Impunity index. Available from: https:// cpj.org/tags/impunity-index2019

Committee to protect journalists (2020). Journalists attacked, harassed while covering Delhi riots. Available from: https://cpj.org/2020/03/at-least-12journalists-harassed-attacked-amid-del.php

COTTLE, S., SAMBROOK, R., \& MOSDELL, N. (2016). Reporting dangerously: journalists killing, intimidation and security. New York, NY, Palgrave, Macmillan.

DALY, E. (2016). Journalists at risk. Annual day promotes accountability for attacks on the media. Human Rights Watch, $2^{\text {nd }}$ November, 2016. Available from: https://www.hrw.org/news/2016/11/02/journalists-risk

DENZIN, N. (1970). The research act: A theoretical introduction to sociological methods. Chicago, IL, Aldine. 
DEWAN, A. (2018). India the most dangerous country to be a woman, US ranks $10^{\text {th }}$ in the survey. $C N N, 26^{\text {th }}$ June, 2018. Available from: https://www.cnn. com/2018/06/25/health/india-dangerous-country-women-survey-intl/index. html

ELLIS-PETERSEN, H. (2021). Twitter concerned for staff in India after row over account removals. The Guardian, $9^{\text {th }}$ February, 2021. Available from: https://www. theguardian.com/world/2021/feb/09/twitter-concerned-for-staff-in-india-afterrow-over-account-removals

FLICK, U. (2000). Triangulation in qualitative research. In: U. E. Flick, E. V. Kardoff, \& I. Steinke, A companion to qualitative research, London, Sage Publications, pp. 178-183.

FUCHS, C. \& HOFKIRCNNER, W. (2009). Autopoiesis and critical social systems theory. In: R. Magalhes \& R. Sanchez, Autopoiesis in organization: Theory and practice, Bingley, UK, Emerald, pp. 111-129.

GEORGE, N. (2016). Supporting safety of journalists in Kenya: An assessment based on UNESCO's journalists' safety indicators. Available from: http://unesdoc. unesco.org/images/0024/002449/244914e.pdf

GOEL, V. \& MASOOD, S. (2020). Facebook, Google and Twitter rebel against Pakistan's censorship rules. The New York Times, $2^{\text {th }}$ February, 2020. https://www. nytimes.com/2020/02/27/technology/pakistan-internet-censorship.html

GREWAL, K. (2020). 'Hinduan ki ladayi hai... record mat kijiye' - journalists under attack in Delhi violence. The Print, $25^{\text {th }}$ February, 2020. Available from: https://theprint.in/india/hinduon-ki-ladayi-hai-record-mat-kijiye-journalistsunder-attack-in-delhi-violence/370758/

GRAY, P., WILLIOMSON, J., KARP, D., \& DALPHIN, J. (2007). The research imagination: An introduction to qualitative and quantitative methods. New York, NY, Cambridge University Press.

GUDIPATY, N. (2017). Gendered public spaces: Online trolling of women journalists in India. Comunicazione Politica, 18, pp. 299-310.

HENRICHSEN, J., BETZ, M., \& LISOSKY, J. (2015). Building digital safety for journalism: A survey of selected issues. Paris, UNESCO Publishing.

HICKS, T. (2013). Why journalists take the risk to report from dangerous places. Nieman Reports, $6^{\text {th }}$ November, 2013. Available from: http://niemanreports.org/ articles/whyjournalists-take-the-risk-to-report-from-dangerous-places/

HUGHES, S. \& MARQUEZ-RAMIREZ, M. (2017). How unsafe contexts and overlapping risks influence journalism practice. Evidence from a survey of Mexican journalists. In: C. Ulla \& P. Reeta, The assault on journalism. Building knowledge to protect freedom of expression, Sweden, Nordicom, University of Gothenburg, pp. 303-316. 
International federation of journalists (2019). Truth vs misinformation: The collective push back. South Asia Press Freedom Report 2018-2019. IN/2019/CI/81. S.1.: International federation of journalists.

International news safety institute (2017). 115 journalists killed in 2016 - year begins and ends with mass casualties. Available from: http://newssafety.org/ news/insi-news/insi-news/detail/115journalists-killed-in-2016-year-begins-andends-with-mass-casualties-1827/

JALIL, X. (2014). Reporting under threat. Testimonies of courage in the face of impunity from Pakistani journalists. Dawn, $25^{\text {th }}$ April, 2014. Available from: https://www.dawn.com/news/1102050

JAMIL, S. (2014). Freedom of expression and press freedom: Journalists' understandings and practices in Pakistan. In: C. Schimdt, Pakistan's media landscape: The effects of liberalization. Bonn, Deutsche Welle Akademie, pp. 46-85.

JAMIL, S. (2015a). Understandings and practices of freedom of expression and press freedom in Pakistan: Ethnography of Karachi journalistic environment. $\mathrm{PhD}$ thesis submitted to the University of Queensland, Australia. Available from: https:// core.ac.uk/download/pdf/43362662.pdf

JAMIL, S. (2015b). Journalists' concepts of freedom of expression and press freedom in Pakistan. Journal of Transnational Worlds of Power: Proliferation of Journalism \& Professional Standards, 1(1), pp. 101-132. New Castle, Cambridge Scholars Publishing.

JAMIL, S. (2016). Journalism practice and freedom of expression: Challenges and constraints in Pakistan. In: B. Lippe \& R. Ottosen, Gendering war and peace reporting: Some insights - some missing links, Gothenburg, Nordicom, pp. 161-176.

JAMIL, S. (2017a). Freedom of expression and journalists' safety: An analysis of conflict reporting and peace journalism education in Pakistan. Journal of the Association of Journalism Education, 6(2), pp. 7-16.

JAMIL, S. (2017b). Freedom under pressure? Threats to journalists' safety in Pakistan. In: U. Carlsson \& R. Poyhtari, Assault on journalism, Gothenburg, Nordicom, pp. 323-329.

JAMIL, S. (2018). Safety threats, impunity and professionalism: Journalists' dilemma in Pakistan. Journal of Sociology and Anthropology, 6, pp. 571-578.

JAMIL, S. (2019a). The handbook of research on combating threats to media freedom and journalists' safety. Hershey, PA, IGI Global.

JAMIL, S. (2019b). Culture of impunity and safety of journalists: Is safe journalism a distant dream in Pakistan? World of Media - Journal of Russian Media and Journalism Studies, 1(1), pp. 51-66. DOI: 10.30547/worldofmedia.1.2019.3 
JAMIL, S. (2020a). Red lines of journalism: Digital surveillance, safety risks and journalists' self-censorship in Pakistan. In: A. G. Larsen, I. Fadnes, \& R. Krovel, Journalist safety and self-censorship, London, Routledge, pp. 29-46.

JAMIL, S. (2020b). Ethnic news media in the digital age: The impact of technological convergence in reshaping journalists' practices in Pakistan. Journal of Multicultural Discourses, 15(2), pp. 219-239.

JAMIL, S. (2020c). Artificial intelligence and journalistic practice: The crossroads of obstacles and opportunities for the Pakistani journalists. Journalism Practice. Available from: https://doi.org/10.1080/17512786.2020.1788412

JAMIL, S. (2020d). Journalism for sustainable development: The imperative of journalists' rights to freedom of expression and access to information for promoting sustainable development in Pakistan. Journal of Applied Journalism and Media Studies, 9(3),pp. 271-291. Available from: https://doi.org/10.1386/ajms_00016_1

JAMIL, S. (2020e). Suffering in silence: The resilience of Pakistan's female journalists to combat sexual harassment and discrimination. Journalism Practice, 14(2), pp. 150-170. Available from: https://doi.org/10.1080/17512786.2020.1725599

JAMIL, S. \& APPIAH-ADJEI, G. (2020a). Discrimination, gender disparity and safety risks in journalism: An introduction. In: S. Jamil, B. Coban, B. Atman, \& G. Appiah-Adjei, The handbook of research on discrimination, gender equality and safety risks in journalism. Pennsylvania, IGI Global, pp. 1-7.

JAMIL, S., \& APPIAH-ADJEI, G. (2020b). Battling with infodemic and disinfodemic: The quandary of journalists to report on COVID-19 pandemic in Pakistan. Media Asia, 44(3-4), pp. 88-109. Available from: https://doi.org/10.108 0/01296612.2020.1853393

JAMIL, S., COBAN, B., ATAMAN, B., \& APPIAH-ADJEI, G. (2020). The handbook of research on discrimination, gender equality and safety risks in journalism. Pennsylvania, IGI Global.

JAMIL, S. \& MUSCHERT, G. (2020). Risks to journalists' safety and the vulnerability of media freedom in the U.S. In: G. Muschert, K. Budd, M. Christian, $\&$ R. Perucci, Agenda for social justice: Solutions for 2020, Bristol, UK, Policy Press.

KPMG (2019). India's digital future: Mass of niches. https://assets.kpmg/ content/dam/kpmg/in/pdf/2019/08/india-media-entertainment-report-2019. pdf

LARRY, K. (2017). An attack on one is an attack on all: Successful initiatives to protect journalists and combat impunity. Available from: http://unesdoc.unesco. org/images/0025/002504/250430e.pdf

LISOSKY, J. \& JENNIFER, H. (2011). War on words: Who should protect journalists? Santa Barbara, Calif., Praeger. 
MAPLECROFT, V. (2019). 'Strongmen' regimes lead charge against freedom of speech and privacy - human rights outlook 2019. Available from: https://www. maplecroft.com/insights/analysis/strongmen-regimes-lead-charge-againstfreedom-of-speech-and-privacy/

MASOOD, A. (2017). Threats to safety of journalists in Pakistan: Risk assessment by journalists at high risk. Available from: https://shareok.org/handle/11244/51917

MAURICE, P., LAVOIE, M., LAFLAMME, L., SVANSTORM, L., ROMER, C., \& ANDERSON, R. (2001). Safety and safety promotion: Definitions for operational developments. Injury Control and Safety Promotion, 8(4), pp. 237-240.

MAXWELL, J. (1997). Designing a qualitative study. In: L. Bickman \& D. J. Rog, Handbook of applied social research methods, Thousand Oaks, CA, Sage, pp. 69-100.

RAO, S. \& WEERASINGHE, P. (2011). Covering terrorism: Examining social responsibility in South Asian journalism. Journalism Practice, 5(4), pp. 414-428.

Reporters without borders (2020). 2020 World press freedom index: Entering a decisive decade for journalism, exacerbated by coronavirus. Available from: https:// rsf.org/en/2020-world-press-freedom-index-entering-decisive-decade-journalismexacerbated-coronavirus

Reporters without borders (2019). World press freedom index. Available from: https://rsf.org/en/ranking_table

RELLY, J. \& GONZALEZ DE MOSTAMANTE, C. (2013). Silencing Mexico: A study of influences on journalists in the Northern states. Available from: http://journals. sagepub.com/doi/abs/10.1177/1940161213509285

RICCHIARDI, S. (2012). Challenges for independent news media in Pakistan: A report to the center for international media assistance. Available from: https:// www.cima.ned.org/wp-content/uploads/2015/01/Challenges-for-IndependentNews-Media-in-Pakistan_Ricchiardi-updated.pdf

RIZWAN, R. (2014). Media safety in Pakistan. Islamabad, Pakistan Institute for Peace Studies.

SEIDL, D. \& BECKER, K. (2013). Niklas Luhmann and organizational studies. Denmark, CBS press.

SHAW, I. (2015). Business journalism: A critical political economy approach. London, Routledge.

SIDDIQUI, F. A. (2017). Threats to journalists in India: Journalism in the age of intolerance and rising nationalism. Reuters Institute Fellowship Paper.

SOHAL, P. (2020). Shooting the messenger, slowly, but surely: A review of imminent threats to freedom of media and journalistic integrity in India. In: S. Jamil, The handbook of research on combating threats to media freedom and journalists' safety. Hershey, PA, IGI Global, pp. 23-37. 
SOHAL, P. K. (2021). Reckoning with \#MeToo and the aftermath: Perception of workplace harassment, sexism, and the \#MeToo movement among journalists in India. In: S. Jamil, B. Coban, B. Atman, \& G. Appiah-Adjei, The handbook of research on discrimination, gender equality and safety risks in journalism. Pennsylvania, IGI Global, pp. 104-118.

Television journalists attacked in northeast Delhi, one serious. The Times of India, 25 $5^{\text {th }}$ February, 2020. Available from: https://timesofindia.indiatimes. com/india/television-journalists-attacked-in-northeast-delhi-one-serious/ articleshow/74302476.cms

VERMEER, H. (2006). Luhmann's 'social systems' theory: Preliminary fragments for a theory of translation. Frank and Timme, GmbH.

WATERSON, J. (2018). Threat to journalists at highest level in 10 years, says report. The Guardian, $5^{\text {th }}$ December, 2018. Available from: https://www. theguardian.com/media/2018/dec/05/threat-journalists-highest-level-10-yearsreport

ZIEMANN, B. (2007). The theory of functional differentiation and the history of modern society. Reflections on the reception of systems theory in recent historiography. Soziale System, 13(1), pp. 220-229. 